\title{
Angel investing in an austerity economy - the take-up of government policies in Portugal
}

\author{
José Bilau, Colin Mason, Tiago Botelho \& Soumodip Sarkar
}

To cite this article: José Bilau, Colin Mason, Tiago Botelho \& Soumodip Sarkar (2017) Angel investing in an austerity economy - the take-up of government policies in Portugal, European Planning Studies, 25:9, 1516-1537, DOI: 10.1080/09654313.2017.1328045

To link to this article: http://dx.doi.org/10.1080/09654313.2017.1328045

曲 Published online: 23 May 2017.

Submit your article to this journal $\pi$

Џll Article views: 79

Q View related articles $₫$

View Crossmark data $\asymp$ 


\title{
Angel investing in an austerity economy - the take-up of government policies in Portugal
}

\author{
José Bilau ${ }^{\mathrm{a}}$, Colin Mason ${ }^{\mathrm{b}}$, Tiago Botelho ${ }^{\mathrm{c}}$ and Soumodip Sarkar ${ }^{\mathrm{d}}$ \\ ${ }^{a}$ Department of Management, Polytechnic Institute of Beja, Beja, Portugal; ${ }^{b}$ Adam Smith Business School, \\ University of Glasgow, Glasgow, UK; ' $N$ orwich Business School, University of East Anglia, Norwich, UK; \\ dDepartment of Management, University of Évora, Évora, Portugal
}

\begin{abstract}
Business angels (BAs) are recognized as playing a significant role in stimulating entrepreneurial activity. With the decline in both bank lending and venture capital investment since the onset of the global economic crisis, government efforts to stimulate BA activity have become a more significant component in strategies to increase the level of entrepreneurial activity. This paper examines the responsiveness of angels to such initiatives in so-called austerity economies - countries that were hardest hit by the financial crisis of 2008 and subsequent global recession and, as a consequence, had to take extreme economic and fiscal measures to reduce their budget deficits. We examine this question in Portugal which experienced one of the deepest recessions in the European Union following the implementation of severe austerity measures. This study confirms that government intervention to support angel investing can have a positive impact. However, the different types of intervention have varied in take-up rates. Other countries can learn from the Portuguese experience in three ways: the types of interventions that have the highest and lowest levels of take-up, the link between the design and the take-up of incentives, and types of intervention that should be considered but have not been implemented in Portugal.
\end{abstract}

\section{ARTICLE HISTORY}

Received 3 August 2016

Revised 10 April 2017

Accepted 3 May 2017

\section{KEYWORDS}

Austerity; entrepreneurship; entrepreneurial finance; business angels; government policy

\section{Introduction}

Business angels (BAs) are recognized in both developed and emerging economies as playing a significant role in stimulating entrepreneurial activity. After family and friends, angel investment is the largest source of external equity financing at the startup and early growth stages (European Business Angels Networks [EBAN], 2016; Sohl, 2012). In addition to the provision of capital, BAs - who are typically experienced business people or successful entrepreneurs - also contribute their experience, knowledge, skills and contacts to the ventures in which they invest. This contribution is particularly important in the earliest stages of the venture when the management team is very likely to be incomplete and inexperienced. BAs have become an even more significant source of finance for entrepreneurial businesses since the onset of the global financial crisis in 
2008. This is for two reasons. First, the financial crisis severely damaged the lending capability of banks, resulting in harsh credit rationing (European Central Bank [ECB], 2013). In parallel, venture capital (VC) firms shifted their focus to later stages of investment where returns are higher, and it is easier to raise new funds, thereby widening the early-stage funding gap (Mason, 2009; OECD, 2011; Sohl, 2012). Second, there is evidence from both Europe and the USA that, in contrast to the availability of bank lending and VC investing, angel investment activity remained fairly stable during the financial crisis and has increased since 2008-2009 (EBAN, 2016; Mason \& Harrison, 2015; Sohl, 2016).

The focus in this paper is on BA investment activity in austerity economies. The decline in tax revenues which followed the financial crisis which began in 2008 exposed many countries in the European periphery - notably Greece, Italy, Portugal, Ireland and Spain - to unsustainable public sector budget deficits. Meanwhile, soaring yields on sovereign bonds made it impossible for these countries to borrow in international markets. In order to receive bailouts from the European Union (EU), ECB and International Monetary Fund (IMF), these countries were forced to introduce austerity measures to reduce government debt. These measures have had adverse impacts on economic growth, investment and employment, unemployment and welfare.

The paper addresses three questions. First, do BAs continue to invest in situations of extreme economic crisis? The financial crisis and austerity measures imposed by the EU, IMF and ECB have caused deep recessions in these countries. There are several possibilities for how this might have affected angel investing. On the supply side, the low returns from conventional asset classes might have stimulated high net worth individuals to seek alternative investments offering the potential for higher returns, although coupled with higher risks. Valuations will also have fallen, reducing the size of investments. Both factors might have resulted in an increased interest in investing by angels. Meanwhile, the decline in bank lending may have overcome the natural aversion of entrepreneurs to equity financing, forcing them to seek BA investment, thereby raising demand for equity finance and, in turn, increasing investment opportunities. However, operating in the opposite direction, reductions in wealth as a result of increases in personal taxes, reduction in asset values and low liquidity of assets, combined with an increase in the perceived risks of investing in early-stage companies, will have discouraged angel investing. Meanwhile, if wealthy investors have increased the off-shoring of their wealth, this will have reduced the liquidity of potential investors. No evidence currently exists on the nature and scale of angel investing in any of the austerity economies.

Second, what has been the effectiveness of policies to promote angel investing in austerity economies? For the reasons noted earlier, policy-makers in various countries have seen BAs as the best means of addressing the persistent and growing funding gap in the seed and early-stage financing market (OECD, 2011). (Whether this is a correct assessment is a separate issue.) On the supply side, this includes tax incentives, co-investment funds, angel networks, training of angel investors, the formation of associations or federations and the creation of appropriate legal conditions for BAs. Policy actions on the demand side have addressed investment readiness issues in order to improve the number of investable opportunities that BAs receive (Mason, 2009; OECD, 2011). These initiatives have increased since the onset of the financial crisis to offset the diminished investment capacity of financial institutions. Portugal already had a network of business angel networks (BANs) in place to enhance the ability of angels to find deals 
and for entrepreneurs seeking finance to locate angels (Bilau \& Sarkar, 2016). It has subsequently introduced fiscal incentives and a co-investment fund. However, it remains unclear how effective such interventions are in supporting angel investing in austerity economies. This paper does not undertake an evaluation in the strict sense of the term. Rather, it examines the responsiveness of angels to the various initiatives that have been introduced in Portugal.

Third, is the policy mix appropriate? We obtain the views of BAs regarding the measures that have been introduced. What are the most and least valued types of support? Do angels think that existing measures need re-designed? Are there other forms of support, perhaps implemented in other countries that might encourage angel investing under conditions of austerity? And given the well-documented heterogeneity of BAs (Avdeitchikova, 2008; Lahti, 2011; Mason, Botelho, \& Zygmunt, 2016), which measures command widespread support and which ones are favoured by specific types of BAs? Two caveats are appropriate. First, just because BAs say that they have a preference for particular initiatives, it does not mean that they will make use of them. Second, those instruments that are most favoured by BAs may not be the ones that have the greatest economic impact.

The study is undertaken in Portugal, which suffered one of the deepest economic recessions in the EU over the crisis years (2008-2012). It was forced to implement an austerity programme as a condition for a $€ 78$ billion bailout from the EU, ECB and IMF. This resulted in cuts in wages and welfare programmes, combined with tax increases, which have eroded family incomes and domestic demand. Meanwhile, small and mediumsized enterprises (SMEs) have struggled to find credit and where it is available interest rates are high, which has reduced the ability of the sector to create jobs. This has resulted in both high unemployment and high levels of migration (at its highest level since the 1960s), especially of skilled workers ('Financial Times (2014) Portugal aims for clean bailout deal', 2014; 'Investing in Portugal', 2014). The country exited from the bailout in May 2014. Since then, it has successfully returned to the international bond market and there are signs that it is emerging from recession ('Investing in Portugal', 2014). Indeed, the economy grew at $0.9 \%$ in 2014, the first full year growth since 2010 .

The remainder of the paper is structured as follows. In the next section, we review the literature on policy interventions to support the development of the BA market. Section 3 provides an overview of Portuguese economy since the financial crisis, followed by and a brief discussion of the implications for the financing environment for SMEs. It also details the measures that have been introduced in Portugal since the onset of the financial crisis to promote BA investment activity. Section 4 describes how the sample was compiled and the procedures used to obtain data. The results of our analysis are presented in Section 5. Section 6 contains the conclusions and policy implications.

\section{Policy interventions to support the development of BA investing}

The rationale for Government intervention to support BAs is that there are inefficiencies in the operation of the market which create barriers to their investment activity. This limits the potential economic impact of their investments and hands-on support on entrepreneurial activity. An international review of policies to stimulate the BA market identifies five main approaches to increase the supply of angel investment and one initiative to 
increase investment opportunities (Mason, 2009; OECD, 2011) (Table 1). However, the available evidence does not consider whether such initiatives are effective or even suitable in conditions of economic austerity, nor whether alternative initiatives might be more appropriate.

The most common initiative is fiscal incentives. These are intended to alter the riskreward balance in investing in new and recently started businesses by reducing the high risks of such investments. These can be structured in several ways: tax relief on the amount invested, exemption of capital gains tax, tax deduction or rolling over for losses, and reinvestment relief on capital gains. Tax incentives are argued to achieve net economic benefits as a result of the economic activity that is generated (investment, creation of firms and jobs and economic growth) (Boyns, Cox, Spires, \& Hughes, 2003). However, Carpentier and Suret (2016) argue that there is limited evidence to confirm a positive outcome, with tax expenditures on incentives for BAs generally exceeding tax revenues when additionality and displacement are considered. There is also evidence (Boyns et al., 2003; Mason, 2009; Mason, Harrison, \& Harrison, 1988) that fiscal incentives attract passive investors (without expertise and contacts) and encourage financial intermediaries to find loopholes to distort the scheme in an effort to reduce investment risks. By reducing the cost of failed investments, they may also discourage some angels from undertaking a thorough evaluation of investment opportunities. Moreover, they do not address the problem of the difficulty that BAs have in finding suitable investment opportunities. A further issue is that the sensitivity of BAs to tax may not be the same across countries (compare UK and Germany: Mason \& Harrison, 1999, 2000; Stedler \& Peters, 2003). Finally, they can be criticized on equity grounds for only benefitting wealthy individuals.

BANs are the longest established initiative to support BAs. They address the high search cost incurred by both entrepreneurs and angels on account of their invisibility to one another which creates discouragement effects (Mason, 2009; Mason \& Harrison, 1999,

Table 1. Policy interventions to support BA investment activity.

\begin{tabular}{|c|c|c|c|}
\hline & Objective & Barrier & Initiative \\
\hline 1 & $\begin{array}{l}\text { To increase the number of investors } \\
\text { and the amount invested }\end{array}$ & High risk of financial loss & Tax incentives \\
\hline 2 & $\begin{array}{l}\text { To overcome discouragement effects } \\
\text { because angels and entrepreneurs } \\
\text { are unable to find another }\end{array}$ & $\begin{array}{l}\text { Angels and entrepreneurs seeking } \\
\text { finance are invisible to one another }\end{array}$ & BANs \\
\hline 3 & Increase deal size & $\begin{array}{l}\text { VCFs have largely withdrawn from the } \\
\text { smaller end of the market creating } \\
\text { a funding gap in the } € 500,000-€ 5 \\
\text { million range (the maximum that } \\
\text { most angels invest and the } \\
\text { minimum most VCFs will invest }\end{array}$ & Co-investment funds \\
\hline 4 & $\begin{array}{l}\text { To raise knowledge and skills of } \\
\text { potential, novice and nascent angels } \\
\text { in order to increase their investment } \\
\text { activity }\end{array}$ & $\begin{array}{l}\text { Knowledge and competence barriers } \\
\text { that discourage high net worth } \\
\text { individuals from becoming angel } \\
\text { investors }\end{array}$ & BA training \\
\hline 5 & $\begin{array}{l}\text { To remove barriers to the ability of } \\
\text { entrepreneurs to promote their } \\
\text { investment opportunities to potential } \\
\text { angel investors }\end{array}$ & $\begin{array}{l}\text { Investor protection rules prevents the } \\
\text { promotion of investment } \\
\text { opportunities to potential investors }\end{array}$ & $\begin{array}{l}\text { Creation of an 'accredited' or } \\
\text { 'sophisticated' investor category } \\
\text { who choose to opt out of } \\
\text { investor protection }\end{array}$ \\
\hline 6 & $\begin{array}{l}\text { To increase the supply of investable } \\
\text { businesses }\end{array}$ & $\begin{array}{l}\text { Because of information asymmetries } \\
\text { entrepreneurs do not understand } \\
\text { the expectations of investors }\end{array}$ & Investment readiness programmes \\
\hline
\end{tabular}


2002; Wetzel, 1987). BANs may also take on the role of facilitating co-investment between BAs. Evidence on their effectiveness is mixed (Collewaert, Manigart, \& Aernoudt, 2010; Harrison \& Mason, 1996; Knyphausen-Aufseß \& Westphal, 2008; Mason \& Harrison, 1999,2002 ) and they have not necessarily resulted an improvement in the quality of deals that angels receive (Mason \& Harrison, 1999). BANs have found it difficult to be financially self-sustaining. Consequently, withdrawal of public sector financial support has typically resulted in their demise. National and international federations of BANs have sought to develop professional standards for angel investing, provide a platform for the dissemination of best practice, organize specific training activities and promote angel investing to build awareness and engage with government (EBAN, 2008; European Commission, 2003; OECD, 2011).

Co-investment funds have been created to address a new equity gap resulting from the shift of VC to larger deals. They operate on the basis of a public fund investing alongside a private investor on the same terms and conditions ('pari passu'), thereby enabling larger investments to be made. Critically, this reduces the need for angels to seek follow-on investments for their investee companies from venture capital funds (VCFs). Investing alongside VCFs creates difficulties for angels on account of the different investment instruments which VCFs use (notably, liquidation preferences, anti-dilution rights, special subscription rights and enhanced follow-on rights) and their different investment motives (notably, the maximization of the fund's returns rather than for every investment to be profitable) (Peters, 2009). In some schemes, the private investment partners (either angel groups or VCFs) are pre-approved. In other cases, the co-fund will make its own decision on each deal that it is presented with. Several European countries and regions now have co-investment schemes. The European Investment Fund currently operates a co-investment fund through its European Angel Fund (EAF) in Austria, Denmark, Germany, Ireland, the Netherlands and Spain. In the future, the EAF will be extended to other European countries and/or regions. ${ }^{1}$ Because co-investment funds are relatively recent, assessments are scarce. The exception is the Scottish Co-investment Fund (SCF) which was established in the early 2000s in response to the dearth of VC in the aftermath of the post-2000 technology crash. An evaluation concluded that it had stimulated the number of investments and made viable investments that in its absence would not have been made, especially larger investments that would require significant follow-up funding. This assessment also highlighted the positive impact that the SCF had on the companies it supported in terms of turnover, gross value added and employment (Hayton, Thorn, Percy, Boyd, \& Latimer, 2008). In addition, co-investment funds can help develop the BA market by attracting new angels and increasing the investment capacity of existing angels and professionalize the angel investment market by providing a more structured investment process (OECD, 2011). An assessment of the early operation of the UK Angel Co-Investment Fund concluded that it had played an important role in expanding the size of the funding round, thereby preventing the risk of 'drip' funding and in some cases avoiding the need for angels to bring a VCF into the deal. However, it had little impact on the formation of angel groups or the dissemination of good practice (Owen \& Mason, 2016). It follows that a key pre-requisite for a successful co-fund is suitable investment partners (Mason, 2009; OECD, 2011). The design of co-investment schemes therefore needs to take account of local conditions (OECD, 2011). 
BA training is another form of intervention that can contribute to developing the BA market. The stereotype of a BA is a successful businessperson with considerable business and entrepreneurial experience and hence with no need for training. However, the BA population is not confined to this investor stereotype (Avdeitchikova, 2008). Moreover, investing in start-ups is a specialized skill, with the recognition and evaluation of opportunities and the structuring of an investment all requiring specialist knowledge. Indeed, it has been established that angels (both active and passive) feel the need to improve their investment skills (San José, Roure, \& and Aernoudt, 2005). Training courses can therefore contribute to the professionalism of existing angels and attract new angels. Training can be delivered through one-off seminars and workshops organized by BANs or angel associations (some of which, like 'The Power of Angel Investing', are now licensed) or by Business Angel Academies which provide regular training programmes over a semester (San José et al., 2005). Previous research indicates that BAs prefer to learn from experienced angel investors and short workshops as opposed to longer courses (Centre for Strategy and Evaluation Services, 2012).

Fifth, securities legislation defines the necessary conditions for the promotion of particular investments or engage in investment activity that protects investors in unquoted companies from less scrupulous promoters. The process, which in the EU is referred to in community directives, involves the prior approval of the investment document by an entity certified for the purpose. It has costs for the applicants. Whilst the intention underlying this legislation is praiseworthy, if the conditions for the promotion of particular investments or to engage in investment activity are too demanding or costly, they can become a barrier to the flow of information from small businesses looking for finance to BAs (Mason, 2009). This, in turn, will reduce both the investment opportunities in those companies and the frequency of BA investments. Various countries therefore define a category of investors - often termed accredited investor and defined in terms of their net worth individual or sophisticated investors - who are permitted to receive invitations to invest that are not required to be pre-approved. In various EU countries, the investments that are promoted by not-for-profit BANs to accredited investors are exempted from securities legislation on the grounds that they do not have any pecuniary interest in the outcome of investments and based on the understanding that they do not give any investment advice or recommend particular investments.

Finally, the main initiative on the demand side is investment readiness programmes which seek to addresses the barriers which constrain the supply of investable opportunities (Mason \& Kwok, 2010). This has three dimensions. First, many entrepreneurs are reluctant to raise equity finance because it means surrendering some ownership and control. This aversion to equity may be related to the entrepreneur's lack of information about the characteristics and availability of alternative sources of finance. The consequence is that many potentially investable projects do not come forward as potential recipients for finance. It is argued that with a better understanding of the role of different sources of finance in business development, more entrepreneurs would consider seeking equity finance. Second, the businesses that seek finance do not meet the requirements of investors. In many cases, this reflects information failure. Relatively few entrepreneurs understand what is needed to attract external equity capital and how to meet the requirements of investors. Third is presentational failings. Even if the underlying proposition is sound, a business may still fail to raise finance if the business plan is poorly constructed and 
presented (Clark, 2008; Mason \& Harrison, 2003). This includes shortcomings in business plans and other written documents that are aimed at investors and deficiencies in 'pitches' at investment forums. There is evidence that BANs which run investment readiness programmes have a significantly higher rate of conversion of companies presented to investors to investments made. However, they also have significantly lower conversion rates from business plans received to companies presented to investors. This suggests that BANs which provide specific investment readiness training are either more selective in the investment opportunities they present to their investors (through the work of their gatekeepers or expert committees that screen the deals) or that businesses are deterred by the increased requirements made of them. In either event, networks offering investment readiness training are, as a consequence, relatively more successful in securing investment for those companies, and the business's chance of success of raising finance is greatly enhanced (Mason \& Harrison, 2010)

\section{The Portuguese economy since 2008: an economy under austerity}

\subsection{The austerity package}

The economic crisis and international financial crisis that erupted in 2008 exposed the underlying weaknesses in the Portuguese economy - notably slow economic growth, trade imbalances and a large deficit in its public finances. By April 2011, the worsening of tensions in the sovereign debt markets and the growing macroeconomic imbalances meant that its banks (which were amongst the least profitable in Europe) lost access to the international wholesale debt market. Faced with this impending cessation of funding, the Portuguese government was forced in May 2011 to negotiate a financial assistance package with the EC, ECB and IMF. This comprised a financing package of $€ 78$ billion which was provided on the basis of a three-year policy programme that contained structural reforms, fiscal measures to reduce the public debt and deficit below $3 \%$ of GDP, and measures to ensure the stability of the country's financial system (EC, 2011).

The package of austerity measures which the Portuguese Government was forced to implement between 2008 and 2012 was of a severity that the country had hitherto never experienced. With the primary goal of fiscal consolidation in mind, the Portuguese government also sought to stabilize the financial sector. It undertook the nationalization (and subsequent sale) of the bank BPN whose accumulated losses were around $€ 700$ million. Several measures to strengthen the liquidity and solvency of the country's banks were also taken, including imposing higher capital adequacy ratios, the creation of a solvency support fund and a reinforcement of the supervisory and regulatory framework. The adjustment package also included wide-ranging expenditure reductions and revenue enhancement measures. On the expenditure side, the measures encompassed cuts in the government's wage bill, involving cuts in the wages of government employees and reductions in number of employees hired in central, regional and local governments. Cuts in social transfers were also imposed (special contributions for pensions above $€ 1500$, suspension of the rule of pension indexation, reduction in public expenditure in the health system, reduction of social benefits). Rail and road investments were postponed. On the revenue side, the government increased the value-added tax (VAT) rate by 2 percentage points, rationalized the VAT structure, including increasing VAT on electricity and gas 
by 6 percentage points to $23 \%$, updated excise taxes, raised taxation on personal incomes, broadened social security contributions and introduced tolls on motorways (OECD, 2012). Other aspects of government policy intervention mandated by the adjustment programme were reforms of the labour market, the judicial system, housing and services sectors, and the privatization of major companies in the utility sector and airports, all with a view to strengthening the economy's growth potential, improving competitiveness and facilitating economic adjustment (OECD, 2012). Other changes have included the easing of product and labour market restrictions and tax reforms including a reduction in corporation tax.

This austerity package resulted in a sharp drop in economic activity, especially on investment and consumption measures. By the last quarter of 2012, the GDP had declined to over $8 \%$ below the 2008 level. Investment by Portuguese companies also registered a sharp decline each year from 2009 and 2012. This reduction was marked by a sharp contraction in domestic demand during that period. The labour market also deteriorated significantly, with the unemployment rate more than doubling from $7.6 \%$ in 2008 to $15.7 \%$ in 2012 and reached $17.5 \%$ a year later. Amongst young people, the unemployment rate in 2012 was 37.7\% (Bank of Portugal, 2013). Wages fell and taxes increased. During this period, Portugal also experienced the return of outmigration at an intensity not witnessed since the early 1960s, comprising mostly young educated and skilled workers. Entrepreneurship has been another escape route from unemployment. In 2012, the total earlystage entrepreneurial activity rate (TEA) reached $7.7 \%$, representing a dramatic increase of $4.5 \%$ from 2010 figures, with the highest entrepreneurship rates occurring amongst 25-34-year-olds (TEA 10.6\% in 2012 GEM Report Portugal, 2013). These new entrepreneurs have been mainly improvement-driven opportunity-motivated (58.3\% in 2012). However, despite this high rate of new firm creation, mortality was even higher, meaning that during this period, there was a net reduction in the overall number of businesses (Bank of Portugal, 2012). The number of companies decreased amongst all size classes, with this fall greatest amongst small and medium enterprises. Many surviving companies were in a precarious situation. Since 2008, almost one in three surviving companies have been overdue with their bank payments and bad loans continue to rise, accounting for $11 \%$ of total bank lending. These are 'zombie' companies that are being kept artificially alive by the banks who prefer to roll over these loans than to take a hit on their equity and bottom lines ('Portugal sets course form', 2014).

These austerity measures have resulted in some progress in the adjustment process of the Portuguese economy, including a gradual reduction of the budget deficit, an increase in GDP, increased consumer confidence, rising employment, and declining unemployment, although this is still high (13\%). Emigration also remains at a high level ('Portugal aims for a clean bailout exit', 2014). The tax burden continues to be high, at $45.2 \%$ of GDP. In summer 2014, Portugal successfully exited from the bailout programme. However, not long after, one of the country's major banks collapsed, raising questions about the extent to which the austerity programme has addressed the country's deep-rooted structural problems ('Investing in Portugal', 2014).

Looking specifically at the impact on access to finance by SMEs, the difficulty of the Portuguese banks in obtaining funding on account of the high interest rates in the sovereign debt bond markets as well as the need to reduce the ratio of loans/deposits have combined to reduce the financing capacity of the banking sector since 2008 . Hence, from the 
beginning of the crisis, there has been an ongoing decrease in loans (new business) as a percentage of GDP and a tightening of other lending conditions (Bank of Portugal, 2013). The interest rate spread has increased continuously since 2008, and was, on average, 2.5 percentage points above the other countries facing financing difficulties (Spain, Ireland, Italy) and 3 percentage points above the eurozone average. In the case of new loans up to $€ 1$ million (which are intended mainly for SMEs), Portugal, along with Greece, has had the highest interest rates in the Eurozone (Jevčák \& Briciu, 2013). There has also been a significant decline in VC activity in Portugal since 2008, with investment activity in 2012 little more than half the 2008 total. Moreover, this investment was dominated by buyouts: 'capital growth' and 'start-up' investments were, respectively, just $14 \%$ and $5 \%$ of total VC investment.

The Portuguese Government has responded to these funding shortfalls with a variety of measures. In order to facilitate the access of SME to bank credit, several state-guaranteed credit lines were created (IFD, 2013). Short-term credit insurance was also made available to support and stimulate export activity. These guarantees had a utilization rate of $89 \%$ in 2012 (IFD, 2013). Government intervention also extended to the VC market. In 2011, it reformed the public risk capital system, merging three existing operators (Inov Capital, Global Capital Aicep and Tourism Capital) into a single entity (Portugal Ventures). The new entity was created with an endowment of $€ 140$ million of available liquidity to fund innovative projects in areas such as biotechnology, pharmaceuticals, information technology, communications and electronics, tourism, maritime economy, forest or agro-industry, energy efficiency; and also for equity participation in companies with export and attract foreign investment vocation. Measures were also introduced to stimulate BA investment activity. These are considered in the next section.

\subsection{The Portuguese policy environment for BA investing}

Portugal has 10 BANs and two national BA associations. This is a similar number to countries such as Sweden, Switzerland, the Netherlands and Italy (OECD, 2011). These BANs are based in each of the regions on the mainland (there are no active BANs in the islands of the Azores and Madeira). Some of the BANs are located in the major cities (e.g. Oporto) whilst others cover smaller inland towns. The range of services offered varies quite considerably between the various BANs (Bilau \& Sarkar, 2016). There are also two national BA associations. The Portuguese Association of Business Angels (APBA), based in Lisbon, was created in 2006 with the mission of stimulating BAs and entrepreneurship activity and supporting the development of regional and sector networks. It performs a dual role, as it operates both as the Federation of Business Angel Networks and as a BAN, but so far, has essentially played the role of a BAN focusing on innovative startups in Greater Lisbon. The Portuguese National Federation of Business Angels (FNABA) was created in 2007 by a group of BANs, with the mission of representing the interests of regional networks established in Portugal. Based on information reported to EBAN, these groups had a total membership of 562 angels in 2012 (cited in Bilau \& Sarkar, 2016).

In 2007, prior to the crisis, the APBA and FNABA had worked with the Portuguese government to develop a specific legal framework for BAs operating in Portugal. This recognized the BA as a specific type of investor (ICR - Investor in Risk Capital) with a similar legal framework to that of venture capitalists. This allows the possibility of 
making investments as individual investors or by adopting the status of a single-person company so as to be able to distinguish the assets allocated to risk capital from the remainder of their personal assets, which is required by the need to guarantee transparency. ICRs are subject to the regulatory framework of financial services and markets set out in the EU's Markets in Financial Instruments Directive and supervised by the Portuguese Securities Market Commission. Following the onset of the crisis, APBA and FNABA again worked with the Portuguese government to introduce two specific measures to support BAs. These are the Business Angels Co-Investment Fund, launched in late 2009, and a $20 \%$ tax relief for BA investments introduced in the 2010 State Budget.

The introduction of a co-investment fund was prompted by the low level of early-stage investment by the VC industry. The COMPETE Business Angels Co-Investment Fund is an initiative of the COMPETE Programme (with European Funding). In December 2009, 54 new BA investment vehicle entities (IVEs) were approved from 67 applications. These are companies that are owned by BAs that will invest in start-ups. A total of 267 angels are involved. Their total investment capacity is $€ 42$ million, with $€ 28$ million from COMPETE, $€ 12.5$ million from BAs and $€ 1.5$ million from Caixa Capital (the VC unit of the Caxio Geral de Depósitos Group - a Portuguese Bank). The funding from COMPETE to the IVE is provided as a 10 -year loan. However, there is no interest or capital return guarantee. BAs are not personally liable for repayment of the amount of the loan to the IVEs. The maximum loan per IVE is $65 \%$ of their total investment requirements up to a maximum of $€ 500,000$ for each IVE. Repayment is structured as follows. Until the total investment of BAs has been returned, the payback is distributed asymmetrically (BA: 80\%/Coinvestment Fund [COF]: 20\%). Once the BAs have had their full investment returned, distribution is symmetric until COMPETE's loan is recovered in full (BA: 50\%/COF: 50\%). After BAs and COMPETE have received back their investments, distribution is proportionate (BA: 80\%/ COF: 20\%). Start-ups must be from the Alentejo, the Centre Region and the North region. Businesses located in Lisbon and the Algarve are excluded from this programme.

The taxation regime differs according to whether the BA activity comes under the scope of ICR - Venture Capital Investor (single-person company) or is made as an individual investor. In the former case, the ICR is subject to company income tax of $25 \%$ of taxable income and a municipality tax up to $1.5 \%$ of taxable income. Capital gains are exempted from tax if the shareholder owns $10 \%$ or more of the company and the investment period is longer than one year. Shareholders' profits are retained at $20 \%$ by withholding tax or added in the amount of $50 \%$ to their personal income taxation. For the individual investor, dividends are retained at $20 \%$ by withholding tax or taxed at $50 \%$ and added to the investor's personal income taxation. Capital gains are exempted from tax if the investment period is over one year. In 2010, the Portuguese State Budget approved a $20 \%$ tax relief for BA investments applicable to both the ICR and the individual investor. However, because of the worsening fiscal position of the country, this benefit was combined with other tax benefits in the following year, which in practice has significantly reduced the value of this tax incentive.

\section{Data sources}

The difficulty of constructing representative samples of BAs is well documented (Mason, 2016; Mason \& Harrison, 2008; Wetzel, 1981). Because of their invisibility, researchers 
have typically had to rely upon samples of convenience. Two sources were used to gather a sample. Working through the APBA and Portuguese Federation of BANs (FNABA), we obtained the agreement of the managers of the 10 local and regional BANs covering the whole of the country to send an e-mail to investors registered with their service, which described the aims of the study and provided a link to the online questionnaire. In the six weeks that followed the e-mail (November-December 2012), 59 valid responses were received (plus seven invalid responses). In addition, we obtained a further 30 responses from angels attending meetings at BANs in six cities across Portugal during the entrepreneurship week in November 2012. These meetings were open to all BAs and not just to BAN members. This approach has minimized two potential sources of bias from the sample. First, by including respondents from all of the BANs in Portugal (large and small, local and regional, inland as well as coastal) this will have minimized the inherent bias in drawing samples from just one BAN (Mason \& Harrison, 1997). Second, respondents include angels who are members of BANs as well as those who are not.

The survey instrument comprised closed questions that asked investors to report about the following:

- investor characteristics: personal and experience background;

- investment activity: number, amounts and results of investments made in the previous five years (since the onset of austerity in 2008), and forecasted number and amounts of investments to be made in the following year;

- use of the new government measures to support BAs in Portugal (tax benefits; co-investment funds) and

- other Government measures that are required to develop the BA market in Portugal.

The questionnaire was piloted with eight BAs identified through informal contacts and recommendations by BAN managers. This resulted in modifications being made to the original survey instrument.

A meaningful response rate cannot be calculated. First, the number of e-mails sent by those in charge of the National Association and Federation (and sent back by BANs) is not known. Second, the number of BAs in the audience of attendees at the meetings is also not known. However, as noted above, the BANs had a total of 562 angel members in 2012. This suggests that our total number of responses (89) represents around $15 \%$ of the visible Portuguese BA population at the time that the survey was undertaken. Nonresponse bias was addressed by means of the procedure suggested by Freear, Sohl, and Wetzel (1994) regarding comparison of early and late respondents online. This did not reveal significant differences.

There are two important limitations to the data that have been collected. First, there is no evidence on the scale of investment activity by respondents prior to the onset of the crisis in 2008. Second, it is possible that in cases where angels co-invested with other angels in the same investment different angels will be reporting on the same deal.

\section{BAs in Portugal: an overview}

The characteristics of respondents are shown in Table 2. Portuguese BAs match the profile that has been established in other studies of BAs. Most Portuguese BAs are male (94\%) and 
Table 2. Characteristics of survey respondents.

\begin{tabular}{|c|c|c|c|c|c|c|c|}
\hline & \multirow[b]{2}{*}{ Characteristic } & \multirow[b]{2}{*}{$n$} & \multirow[b]{2}{*}{$\%$} & \multicolumn{4}{|c|}{ Compete co-investment status } \\
\hline & & & & $\begin{array}{c}\text { Approved } \\
\text { applicants } \\
N\end{array}$ & $\%$ & $\begin{array}{l}\text { Applicants who did not apply } \\
\text { or were not approved } \\
N\end{array}$ & $\%$ \\
\hline \multirow[t]{3}{*}{ Gender } & Male & 84 & 94.4 & 38 & 95 & 46 & 94 \\
\hline & Female & 5 & 5.6 & 2 & 5 & 3 & 6 \\
\hline & Total & 89 & 100 & 40 & 100 & 49 & 100 \\
\hline \multirow[t]{7}{*}{ Age (years) } & $<25$ & 1 & 1.1 & 1 & 3 & 0 & 0 \\
\hline & $26-30$ & 1 & 1.1 & 1 & 3 & 0 & 0 \\
\hline & $31-40$ & 18 & 20.2 & 6 & 15 & 12 & 24 \\
\hline & $41-50$ & 33 & 37.1 & 18 & 45 & 15 & 31 \\
\hline & $51-60$ & 22 & 24.7 & 9 & 23 & 13 & 27 \\
\hline & $>60$ & 14 & 15.7 & 5 & 13 & 9 & 18 \\
\hline & Total & 89 & 100 & 40 & 100 & 49 & 100 \\
\hline \multirow[t]{7}{*}{ Education } & $\begin{array}{l}\text { Basic education } \\
\text { (9 years) }\end{array}$ & 2 & 2.2 & 0 & 0 & 2 & 4 \\
\hline & $\begin{array}{l}\text { Secondary education } \\
\text { (12 years) }\end{array}$ & 6 & 6.7 & 0 & 0 & 6 & 12 \\
\hline & Degree & 33 & 37.1 & 17 & 43 & 16 & 33 \\
\hline & Post-graduate & 19 & 21.3 & 6 & 15 & 13 & 27 \\
\hline & Master or Ph.D. & 28 & 31.5 & 17 & 43 & 11 & 22 \\
\hline & $\begin{array}{l}\text { Professional } \\
\text { qualifications }\end{array}$ & 1 & 1.1 & 0 & 0 & 1 & 2 \\
\hline & Total & 89 & 100 & 40 & 100 & 49 & 100 \\
\hline \multirow[t]{9}{*}{ Occupation } & Entrepreneur & 38 & 42.7 & 15 & 38 & 23 & 47 \\
\hline & Administrator & 13 & 14.6 & 9 & 23 & 4 & 8 \\
\hline & Director or manager & 9 & 10.1 & 4 & 10 & 5 & 10 \\
\hline & $\begin{array}{l}\text { Independent } \\
\text { professional }\end{array}$ & 3 & 3.4 & 0 & 0 & 3 & 6 \\
\hline & Consultant & 12 & 13.5 & 7 & 18 & 5 & 10 \\
\hline & Professional investor & 5 & 5.6 & 4 & 10 & 1 & 2 \\
\hline & Retired & 5 & 5.6 & 1 & 3 & 4 & 8 \\
\hline & Other situation & 4 & 4.5 & 0 & 0 & 4 & 8 \\
\hline & Total & 89 & 100.0 & 40 & 100 & 49 & 100 \\
\hline \multirow{5}{*}{$\begin{array}{l}\text { Start-up } \\
\text { experience }\end{array}$} & No experience & 4 & 4.5 & 0 & 0 & 4 & 8 \\
\hline & One company & 12 & 13.5 & 3 & 8 & 9 & 18 \\
\hline & $\begin{array}{l}\text { Two or three } \\
\text { companies }\end{array}$ & 30 & 33.7 & 10 & 25 & 20 & 41 \\
\hline & $\begin{array}{c}\text { Four or more } \\
\text { companies }\end{array}$ & 43 & 48.3 & 27 & 68 & 16 & 33 \\
\hline & Total & 89 & 100.0 & 40 & 100 & 49 & 100 \\
\hline \multirow{3}{*}{$\begin{array}{c}\text { Management } \\
\text { experience }\end{array}$} & Yes & 86 & 96.6 & 39 & 98 & 47 & 96 \\
\hline & No & 3 & 3.4 & 1 & 3 & 2 & 4 \\
\hline & Total & 89 & 100.0 & 40 & 100 & 49 & 100 \\
\hline \multirow{5}{*}{$\begin{array}{l}\text { Industry } \\
\text { experience }\end{array}$} & No experience & 6 & 6.7 & 5 & 13 & 1 & 2 \\
\hline & Under 5 years & 15 & 16.9 & 6 & 15 & 9 & 18 \\
\hline & $>5$ and $<10$ years & 9 & 10.1 & 1 & 3 & 8 & 16 \\
\hline & $>10$ years & 59 & 66.3 & 28 & 70 & 31 & 63 \\
\hline & Total & 89 & 100.0 & 40 & 100 & 49 & 100 \\
\hline
\end{tabular}

41-60 years old (62\%). They have a high level of education (90\% have at least a first degree). The overwhelming majority have management experience, with over twothirds having more than 10 years of experience in industry. Most have entrepreneurial backgrounds (with $80 \%$ having founded two or more businesses).

Responses were received from BAs located in 14 of the 18 districts of mainland Portugal. The regional distribution of BAs is weighted towards Lisbon (34\%) and Porto (15\%) which are the two wealthiest and most developed districts in Portugal. However, the fact that half of the respondents are located in the remainder of the country confirms that, as 
reported in other countries (e.g. Avdeitchikova, 2009; Gaston, 1989), angel investors are widely distributed geographically.

Just under three-quarters (73\%) of respondents had made at least one investment in the period of austerity (2008-2012). Some 14\% did not invest at all in that period, nor were they considering making investments in the following year. Of the remainder, $10 \%$ indicated that they had not made any investment in that period but foresaw doing so in the next 12 months. The remaining 3\% of BAs did not invest and have no specific investment plans but were open to making investments. For those angels who have been active in the austerity era, the most common pattern has been to make three or four investments (33\% of respondents). These investors typically invested between $€ 100,000$ and $€ 250,000$ range. The majority of the investments that the respondents made in this period (64\%) were still in their portfolios. However, some exits had occurred, with $12 \%$ being sold for a financial gain (21\% of angels). Of the remainder, $6 \%$ were sold at break-even (13\% of investors) and $22 \%$ had failed ( $20 \%$ of investors). A vast majority ( $83 \%)$ of respondents envisaged making investments in the next 12 months. However, most of these investors expected only to make one investment (31\%). A majority of these investors (63\%) expected to invest under $€ 100,000$.

\section{The take-up of government measures}

\subsection{New measures}

Just under half (45\%) of the BAs in the sample have participated in an IVE approved by the COMPETE BAs Co-Investment Fund (Table 2). Of these, 65\% reported that their IVE had made between one and three investments. This compares with 35\% whose IVE had not yet made any investments (Table 3). It is, of course, possible that responding BAs are part of the same IVE.

There were no differences in terms of age between BAs participating in the co-investment fund and those not participating (see Table 2 columns 5-8). ${ }^{2}$ However, differences can be found in terms of education, start-up experience, entrepreneurial experience and industry experience. First, in terms of education, investors participating in the COMPETE programme were more likely to have a higher degree (Masters/Ph.D.) (43\% cf. 37\%). Second, all respondents who participated in the COMPETE programme (and most of those who did not participate) had start-up business experience. However, participants in the COMPETE programme had started more companies (68\% had started four or more companies, cf. $33 \%$ ), but a smaller proportion (38\% cf. $47 \%$ ) were active entrepreneurs at the time of the study. Third, those angels who participated in the co-investment fund had both more industry experience (70\% had more than 10 years cf. $63 \%)$ and also

Table 3. Investments made by BAs participating in the COMPETE co-investment fund.

\begin{tabular}{lcc}
\hline No of investments made & Frequency & Percent \\
\hline 0 & 14 & 35.0 \\
1 & 8 & 20.0 \\
2 & 8 & 20.0 \\
3 & 10 & 25.0 \\
Total & 40 & \\
\hline
\end{tabular}


less industry experience ( $13 \%$ had no experience compared with only $2 \%$ of the other group) members.

Of those angels who had made at least one investment in period 2008-2012 $(n=65)$, only $32 \%$ said that they had taken advantage of the new fiscal incentives. This low proportion is explained by two factors. First, the scheme was only introduced in 2010, hence investments made prior to this date did not benefit. Second, from 2011 onwards, an upper limit on all forms of tax relief was introduced. This meant that investors who might have claimed under this scheme did not do so because they had already reached their limit from other forms of tax exemptions. In addition, the tax benefits available for individuals with higher incomes - the income category that would be expected to include most BAs - were cut, thereby limiting their eligibility for tax relief.

\subsection{Angel views on incentives needed to stimulate investment activity}

Participants were then asked what measures they thought were needed in the present conditions of financial austerity to encourage greater investment activity. They were asked to rate a list 19 specific measures in five different areas (fiscal measures; BA training; legislative regime; support BANs; co-investment schemes) on a 1-7 scale (Table 4).

The results provide clear evidence for the preference of BAs for fiscal measures to encourage investment activity in conditions of austerity. 'Reinvestment relief and 'tax relief on the amount invested' were cited by respondents as, respectively, the most important and third most important types of incentives. The one fiscal measure that attracted little support was tax exemptions on income from dividend income. As angels are

Table 4. Angel views on ways to stimulate BAs investments.

\begin{tabular}{|c|c|c|c|}
\hline $\begin{array}{l}\text { Types of measures to stimulate } \\
\text { BAs investments }\end{array}$ & Specifics measures & $\begin{array}{l}\text { Mean } \\
\text { score }\end{array}$ & Rank \\
\hline \multirow[t]{4}{*}{ Fiscal measures } & (a) Tax relief on the amount invested & 5.66 & 3 \\
\hline & (b) Tax exemption on income & 4.68 & 17 \\
\hline & (c) Exemption of capital gains from & 5.09 & 10 \\
\hline & (d) Tax reinvestment relief & 5.89 & 1 \\
\hline \multirow[t]{3}{*}{ BA training } & $\begin{array}{l}\text { (e) Provide BAs with the specialist knowledge and skills they } \\
\text { require to invest successfully }\end{array}$ & 4.77 & 15 \\
\hline & $\begin{array}{l}\text { (f) Support training of young BAs (understanding the investment } \\
\text { process) }\end{array}$ & 5.18 & 7 \\
\hline & (g) Support training of women BAs & 5.07 & 13 \\
\hline \multirow[t]{2}{*}{ Juridical regime } & $\begin{array}{l}\text { (h) Information barriers in legislation (sale of shares within } 5 \\
\text { years) }\end{array}$ & 5.59 & 4 \\
\hline & $\begin{array}{l}\text { (i) Information barriers in legislation (bureaucracy, registration } \\
\text { and prior notice) }\end{array}$ & 5.46 & 6 \\
\hline \multirow[t]{7}{*}{ Support BANs } & $\begin{array}{l}\text { (j) BANs' activity of improving the efficiency of investment } \\
\text { opportunities }\end{array}$ & 5.53 & 5 \\
\hline & (k) BANs' activity of raising awareness of the BA market & 5.08 & 11 \\
\hline & $\begin{array}{l}\text { (I) BANs' activity to increase the interaction between BAs and } \\
\text { formal VC }\end{array}$ & 5.08 & 11 \\
\hline & (m) BANs' activity to facilitate angel syndicates & 4.81 & 14 \\
\hline & $\begin{array}{l}\text { (n) BANs' activity to support the activity of capacity building } \\
\text { (investor training) }\end{array}$ & 4.51 & 18 \\
\hline & $\begin{array}{l}\text { (o) BANs' activity to support the activity of promoting investment } \\
\text { forums, fairs and workshops }\end{array}$ & 4.77 & 15 \\
\hline & (p) Underwriting BANs' running costs & 3.67 & 19 \\
\hline \multirow[t]{3}{*}{ Co-investment schemes } & (q) Passive co-investment funds & 5.84 & 2 \\
\hline & (r) Actively managed co-investment funds & 5.12 & 9 \\
\hline & (s) Internationalization co-investment funds & 5.15 & 8 \\
\hline
\end{tabular}


investing for capital gain rather than income, this response is not surprising. Angel investors scored it as the third least attractive measure. Only the provision of training in the specialist knowledge and skills required to invest successfully and support for BANs to run investment forum, fairs and workshops attracted lower scores.

The importance of co-investment schemes was also emphasized by the respondents, with this measure attracting the second highest score. The other measures in the top five were the removal of the restriction on the sale of shares within five years (fourth) (contained in the ICR statutory framework) and support for BANs to address the information asymmetry problem caused by the high search cost for entrepreneurs and angels as they try to find one another (fifth). Looking in more detail at investors' views on the activities of BANs, there is a consensus that they should focus their activities on improving the efficiency of the investment opportunities (deal flow) rather than capacity-building activity (investor training) and investment forums, fairs and workshops. Indeed, three of the five lowest scoring measures are related to the activities of BANs. As respondents are mostly quite experienced investors, this response is to be expected.

\subsection{The implications of the heterogeneity of angels for policy targeting}

It is well established that BAs comprise a heterogeneous population (Avdeitchikova, 2008; Lahti, 2011). This provides a challenge to policy-makers because of the likelihood that angels will vary in their responsiveness to specific measures. This section examines whether there are specific characteristics of the angel investors that influence the types of incentives that they do, and do not, favour. Using a chi-square analysis, there were statistically significant differences on both the five most favoured and the five least favoured measures.

Of the top five measures (Table 5), there were two - reinvestment relief and improvements in the efficiency of investment opportunities - that attracted support from all types of angels. There is a clear link between support for passive co-investment funds and the level of experience of the angel investor. This measure was rated higher by more experienced BAs and also by angels with the most experience of investing with co-funds. This statistical difference is also found when controlling for start-up experience, with angel investors who had never started a firm giving less emphasize to this measure. A Kruskal-Wallis test also revealed a statistically significant difference in support for 'tax relief on the amount invested' which was valued most strongly by angels expecting to make smaller investments. Restrictions on the sale of shares was also statistically significant when controlling for the willingness to make future investments and for investment outcomes. Angels who have not achieved any exits were more supportive of this measure than those who had made exits. Angels who expect to make more investments in the future also scored more highly restrictions on the sale of shares than those who were less likely to invest. Two additional controls were also statistically significant: education and the GDP of the region in which the angel lived. Investors from richer regions scored this measure higher than their equivalents from low GDP regions. Angels with no higher education scored this measure lower.z

Only two of the bottom five measures present statistical differences between angels (Table 6). Novice angels rank investment forums, fairs and workshops higher than their nascent and experienced counterparts. This could be associated with network effects. 
Table 5. Most popular measures to stimulate the BA market: Kruskal-Wallis test (chi-square statistic/df/significance level).

\begin{tabular}{|c|c|c|c|c|c|c|c|c|c|c|c|c|}
\hline $\begin{array}{l}\text { Variables (Likert } \\
\text { scale 1-7) }\end{array}$ & $\begin{array}{l}\text { Measure } \\
\text { types }\end{array}$ & $\begin{array}{l}\text { Number of } \\
\text { investments } \\
\text { forecast (next } \\
\text { year) }\end{array}$ & $\begin{array}{l}\text { Amount of } \\
\text { investment } \\
\text { forecast (next } \\
\text { year) }\end{array}$ & $\begin{array}{l}\text { Positive } \\
\text { investment } \\
\text { outcome }\end{array}$ & $\begin{array}{c}\text { Negative } \\
\text { investment } \\
\text { outcome }\end{array}$ & $\begin{array}{l}\text { Investment } \\
\text { experience }\end{array}$ & $\begin{array}{l}\text { Experience } \\
\text { with the co- } \\
\text { fund }\end{array}$ & Age & Education & $\begin{array}{c}\text { Start-up } \\
\text { experience }\end{array}$ & $\begin{array}{l}\text { GDP } \\
\text { region }\end{array}$ & $\begin{array}{l}\text { Industry } \\
\text { experience }\end{array}$ \\
\hline \multirow{3}{*}{$\begin{array}{l}\text { (1) Reinvestment } \\
\text { relief }\end{array}$} & \multirow{3}{*}{ Fiscal measures } & 0.712 & 3.324 & 0.041 & 0.002 & 1.428 & 4.980 & 2.347 & 1.227 & 1.868 & 0.096 & 5.938 \\
\hline & & 2 & 2 & 1 & 1 & 2 & 2 & 3 & 2 & 2 & 1 & 3 \\
\hline & & 0.700 & 0.190 & 0.840 & 0.962 & 0.490 & 0.083 & 0.504 & 0.541 & 0.393 & 0.756 & 0.115 \\
\hline \multirow{3}{*}{$\begin{array}{l}\text { (2) Passive co- } \\
\text { investment funds }\end{array}$} & \multirow{3}{*}{$\begin{array}{l}\text { Co-investment } \\
\text { funds }\end{array}$} & 4.292 & 4.351 & 0.319 & 1.231 & 6.144 & 10.264 & 2.203 & 3.896 & 7.469 & 0.897 & 6.083 \\
\hline & & 2 & 2 & 1 & 1 & 2 & 2 & 3 & 2 & 2 & 1 & 3 \\
\hline & & 0.117 & 0.114 & 0.572 & 0.267 & $0.046^{\mathrm{a} *}$ & $0.006^{b * *}$ & 0.531 & 0.143 & $0.024^{\mathrm{C} *}$ & 0.344 & 0.108 \\
\hline \multirow{3}{*}{$\begin{array}{l}\text { (3) Tax relief on the } \\
\text { amount invested }\end{array}$} & \multirow{3}{*}{ Fiscal measures } & 0.915 & 7.138 & 2.548 & 1.575 & 0.715 & 3.863 & 2.575 & 5.992 & 1.252 & 0.298 & 2.020 \\
\hline & & 2 & 2 & 1 & 1 & 2 & 2 & 3 & 2 & 2 & 1 & 3 \\
\hline & & 0.633 & $0.028^{\mathrm{C} *}$ & 0.110 & 0.209 & 0.699 & 0.145 & 0.462 & 0.050 & 0.535 & 0.585 & 0.568 \\
\hline \multirow{3}{*}{$\begin{array}{l}\text { (4) Restrictions on } \\
\text { the sale of shares } \\
\text { within } 5 \text { years }\end{array}$} & \multirow{3}{*}{$\begin{array}{l}\text { Juridical } \\
\text { regime }\end{array}$} & 8.937 & 4.447 & 4.114 & 3.092 & 3.806 & 3.673 & 2.332 & 6.021 & 0.374 & 4.467 & 4.279 \\
\hline & & 2 & 2 & 1 & 1 & 2 & 2 & 3 & 2 & 2 & 1 & 3 \\
\hline & & $0.011^{\mathrm{C} *}$ & 0.108 & $0.043^{*}$ & 0.079 & 0.149 & 0.159 & 0.506 & $0.049^{\mathrm{b} *}$ & 0.829 & $0.035^{\mathrm{d}_{*}}$ & 0.233 \\
\hline \multirow{3}{*}{$\begin{array}{l}\text { (5) Improve the } \\
\text { efficiency of } \\
\text { investment } \\
\text { opportunities }\end{array}$} & \multirow[t]{3}{*}{ Support BANs } & 1.093 & 0.669 & 0.866 & 0.000 & 0.369 & 1.140 & 1.460 & 2.222 & 0.396 & 0.117 & 1.550 \\
\hline & & 2 & 2 & 1 & 1 & 2 & 2 & 3 & 2 & 2 & 1 & 3 \\
\hline & & 0.579 & 0.716 & 0.352 & 1.000 & 0.831 & 0.566 & 0.691 & 0.329 & 0.821 & 0.732 & 0.671 \\
\hline
\end{tabular}

${ }^{\mathrm{a} A}$ Dunn's non-parametric test detected a statistically significant relationship between groups 1 and 3 .

${ }^{\mathrm{b}}$ A Dunn's non-parametric test detected a statistically significant relationship between groups 1 and 2, and groups 1 and 3 .

'A Dunn's non-parametric test detected a statistically significant relationship between groups 1 and 2 .

Mann-Whitney U-test detected a statistically significant relationship between groups 1 and 2 .

${ }^{*} p<.05$.

${ }^{* *} p<.01$. 
Table 6. Least popular measures to stimulate the BA market - Kruskal-Wallis test (chi-square statistic /df/significance level).

\begin{tabular}{|c|c|c|c|c|c|c|c|c|c|c|c|c|}
\hline Variables & Measure types & $\begin{array}{l}\text { Number of } \\
\text { investments } \\
\text { forecast } \\
\text { (next year) }\end{array}$ & $\begin{array}{l}\text { Amount of } \\
\text { investment } \\
\text { forecast } \\
\text { (next year) }\end{array}$ & $\begin{array}{l}\text { Positive } \\
\text { investment } \\
\text { outcome }\end{array}$ & $\begin{array}{l}\text { Negative } \\
\text { investment } \\
\text { outcome }\end{array}$ & $\begin{array}{l}\text { Investment } \\
\text { experience }\end{array}$ & $\begin{array}{l}\text { Experience } \\
\text { with the co- } \\
\text { fund }\end{array}$ & Age & Education & $\begin{array}{l}\text { Start-up } \\
\text { experience }\end{array}$ & $\begin{array}{l}\text { GDP } \\
\text { region }\end{array}$ & $\begin{array}{l}\text { Industry } \\
\text { experience }\end{array}$ \\
\hline \multirow{3}{*}{$\begin{array}{l}\text { (1) Underwrite BANs' } \\
\text { running costs }\end{array}$} & \multirow[t]{3}{*}{ Support BANs } & 5.831 & 2.912 & 0.118 & 0.239 & 1.632 & 0.751 & 4.369 & 0.175 & 1.275 & 0.082 & 3.612 \\
\hline & & 2 & 2 & 1 & 1 & 2 & 2 & 3 & 2 & 2 & 1 & 3 \\
\hline & & 0.054 & 0.233 & 0.732 & 0.625 & 0.442 & 0.687 & 0.224 & 0.916 & 0.529 & 0.774 & 0.307 \\
\hline \multirow{3}{*}{$\begin{array}{l}\text { (2) Support the activity } \\
\text { of capacity building } \\
\text { (training for } \\
\text { investors) }\end{array}$} & \multirow[t]{3}{*}{ Support BANs } & 5.414 & 1.578 & 1.653 & 0.057 & 0.639 & 1.363 & 5.694 & 1.017 & 3.436 & 0.375 & 3.815 \\
\hline & & 2 & 2 & 1 & 1 & 2 & 2 & 3 & 2 & 2 & 1 & 3 \\
\hline & & 0.067 & 0.454 & 0.199 & 0.811 & 0.727 & 0.506 & 0.127 & 0.602 & 0.179 & 0.540 & 0.282 \\
\hline \multirow{3}{*}{$\begin{array}{l}\text { (3) Tax exemption on } \\
\text { income }\end{array}$} & \multirow[t]{3}{*}{ Fiscal measures } & 5.120 & 0.413 & 1.854 & 2.723 & 0.195 & 2.167 & 7.548 & 1.945 & 3.047 & 0.409 & 0.159 \\
\hline & & 2 & 2 & 1 & 1 & 2 & 2 & 3 & 2 & 2 & 1 & 3 \\
\hline & & 0.077 & 0.813 & 0.173 & 0.099 & 0.907 & 0.338 & 0.056 & 0.378 & 0.218 & 0.523 & 0.984 \\
\hline \multirow{3}{*}{$\begin{array}{l}\text { (4) Provide BAs with } \\
\text { the specialist } \\
\text { knowledge and skills } \\
\text { they require to invest } \\
\text { successfully }\end{array}$} & \multirow[t]{3}{*}{ Support for BAs training } & 4.191 & 4.348 & 0.112 & 0.334 & 4.975 & 0.442 & 14.018 & 1.223 & 2.437 & 0.271 & 2.637 \\
\hline & & 2 & 2 & 1 & 1 & 2 & 2 & 3 & 2 & 2 & 1 & 3 \\
\hline & & 0.123 & 0.114 & 0.738 & 0.563 & 0.083 & 0.802 & $0.003^{a * *}$ & 0.542 & 0.296 & 0.603 & 0.451 \\
\hline \multirow{3}{*}{$\begin{array}{l}\text { (5) Promote investment } \\
\text { forums, fairs and } \\
\text { workshops }\end{array}$} & \multirow[t]{3}{*}{ Support BANs } & 3.180 & 3.971 & 1.402 & 0.017 & 10.222 & 0.697 & 10.475 & 2.818 & 2.963 & 1.136 & 0.179 \\
\hline & & 2 & 2 & 1 & 1 & 2 & 2 & 3 & 2 & 2 & 1 & \\
\hline & & 0.204 & 0.137 & 0.236 & 0.898 & $0.006^{b_{* *}}$ & 0.706 & $0.015^{c_{*}}$ & 0.244 & 0.227 & 0.287 & 0.981 \\
\hline
\end{tabular}

${ }^{a}$ A Dunn's non-parametric test detected a statistically significant relationship between groups 4 and 1, and groups 4 and 3.

${ }^{b}$ A Dunn's non-parametric test detected a statistically significant relationship between groups 2 and 1 , and groups 2 and 3 .

'A Dunn's non-parametric test detected a statistically significant relationship between groups 4 and 1, and groups 4 and 2 e 4 and 3 .

${ }^{*} p<.05$.

${ }_{* *}^{* *} p<.01$. 
Novice angels are likely to have smaller networks than experienced angels; hence, they might be expected to give greater emphasis to measures that improve their deal flow. However, nascent angels might have even a smaller network and so could have been expected to value this measure more highly than novices. The explanation may be that until they start to invest, they do not appreciate the value of networks. There were also statistical differences when controlling for age of the investor, with older investors showing less interest in this measure. Providing BAs with specialist knowledge and skills to invest successfully was also given less support by the older age group of investor, presumably because they feel that they have sufficient investment experience when compared with younger investors.

It needs to be acknowledged that some of these findings could be type II errors, explained by random sampling error or chance (Urdan, 2005). A type II error happens when a false null hypothesis is not rejected. Dougherty (2016) has noted that high significance levels will increase the likelihood of type II error. Hence, some of these results should be further researched to provide a clearer picture of the possible explanations.

\section{Conclusions and policy implications}

Following the onset of the financial crisis in 2008, a number of EU countries with high debt levels were forced to seek bailouts from the EU, ECB and IMF. As a condition, they had to make dramatic spending cuts. The austerity measures that were implemented led directly to the deterioration of the financial environment. The consequence was a decline in both bank lending and VC investing which, in turn, resulted in depressed economic activity levels. The consequence is that BAs as source of finance for entrepreneurial businesses in such countries, have now become even more significant. Recognising this, governments have responded by implementing various measures intended to increase BA investment activity. The paper examines the impact of such intervention in socalled austerity economies - that is, countries in the periphery of the euro zone that have been the worst hit by the financial crisis. Portugal - which suffered one of most significant economic declines in the EU in the period 2008-2012 - provided the geographical context in which to examine this issue. Four conclusions can be drawn from the analysis.

First, BAs in Portugal continued to invest during the financial crisis. The typical BA made three or four investments, invested between $€ 100,000$ and $€ 250,000$. Moreover, some $80 \%$ stated their intention to invest in the next 12 months, even though the process of economic adjustment was expected to continue and possibly even worsen over this period.

Second, the impact of the various government initiatives - which is measured here in terms of take-up rates - has varied. In the depths of austerity in late 2009, policy-makers launched a co-investment fund for BAs. The initial challenge seems to have been successfully overcome, with a significant number of IVEs (56) being created involving 267 BAs. Moreover, $45 \%$ of BAs now have participated in these IVEs and had already made investments. These results have been confirmed by the interim report of COMPETE (2013), which concluded that the investments made by the Portuguese co-investment fund had reached $€ 8.9$ million by the end of 2012 . There was no significant difference in the participation of BAs in the co-investment fund by region. Highly educated BAs and those with greater investment activity in the years of austerity had the greatest involvement with the 
co-funds initiative. An unequivocal association is also found between the support received from BANs and the participation of businesses angels in the scheme. This support was in the form of dissemination, making their members aware of the scheme's advantages, and support in the bureaucratic process of application. This suggests that in a developing BA market, BANs can play an important role in the success of these types of measures.

However, the tax relief instrument for angel investment in force in Portugal during the period of austerity was less effective, used by less than one-third of investments by BAs. This can be explained by three factors. The benefit had only been in force two years prior to the study. Tax changes were made in 2011 which capped the tax benefits from this and other schemes, thereby putting a limit the annual amount deductible and tax relief for high-income individuals - the income category of most BAs - was reduced.

In summary, although the study confirms that government intervention to support angel investment can have a positive impact (measured in terms of take-up), this needs to be qualified in two respects. Different types of intervention appeal to different types of BA, with implications for their effectiveness. And the design of incentives influences their effectiveness.

Third, in terms of their preferences for measures to encourage investment activity in the present conditions of financial austerity, BAs expressed strongest support for two types of tax incentives: 'tax reinvestment relief and 'tax relief on the amount invested'. The latter measure is particularly supported by BAs who expect to make smaller investments. This is a dominant characteristic of the BAs in the sample, so the introduction of 'tax reinvestment relief measure in 2010 seems to have been appropriate for the Portuguese context. However, the effectiveness of tax relief was significantly reduced or cancelled out one year after its introduction because of important changes to the taxation regime that were introduced by the State Budget of 2011. There was also support by BAs for co-investment schemes. They indicated a preference for passive co-investment funds in which investment occurs automatically without investment selection filters because it eliminates uncertainty for investors. However, as this has been the model that was implemented, it may be the only one that respondents have knowledge of. BAs also included amongst their most favoured measures the elimination of the prohibition on selling shares within five years.

Finally, Portuguese BAs consider that government support for BANs in period of crisis should be primarily directed to supporting activities that improve the efficiency of market, notably the promotion of investment opportunities to reflect the ongoing significance of information asymmetries in the market. Lower emphasis was given to support for the running costs of BANs and for capacity-building activities (e.g. training for investors). The latter may be a function of the sample which comprises experienced and highly educated angels. However, angels did think that it was important to direct support to the training of young and women BAs.

There are three implication for policy-makers in other austerity economies. First, the angel market continues to operate even in conditions of austerity. Second, the take-up, and hence potential effectiveness, of government intervention varies according to the type of measure. In the case of Portugal, fiscal incentives have had a low take-up rate amongst BAs. This may suggest the need to adjust the current eligibility conditions for tax relief on the amount invested, or replace it with tax reinvestment relief, which was the measure of a fiscal nature most highly valued by BAs. The co-investment fund was 
only implemented two years before the survey; hence, it was too early to make an assessment of its impact. However, in terms of the take-up (54 IVE with 267 BAs), together with the views of angels on the design of such schemes, it would appear that government's choice of a passive fund is an effective mechanism to stimulate the BA market in austerity period. The results also indicate that BANs have played an important role in dissemination and in supporting the participation of BAs in the co-investment fund across different regions (including the poorest regions) and continue to be important in increasing awareness of angel investing. Ongoing Government support for BANs (preferably based on a regional model) is therefore essential. The negative assessment by BAs of some aspects of the new legal framework for BAs is a warning that public authorities should take the needs of BAs into account when new legislation or rules are introduced. Legitimate BA activity should not be inhibited by legislation. Third, although some measures to promote BA investment have generic appeal to all types of angels, there are others where the appeal, and hence take-up, varies across the BA population. Key characteristics of angels that differentiate their response to specific measures are their investment experience, age and scale of investing. Two related implications follow. First, active angels and those making larger investments are likely to be the most active in lobbying government, for example, via the angel associations. However, policy-makers have to understand that the measures advocated by these angels may not be appropriate for encouraging nascent and novice angels to invest and so should not be over-influenced by the views of this segment of the angel population. Second, our evidence shows that the objective of expanding the number of active BAs (i.e. increasing the number of nascent and novice angels) requires different measures from the objective of encouraging existing and active investors to increases their investment activity.

\section{Notes}

1. http://www.eif.org/what_we_do/equity/eaf/.

2. There were also no differences by region.

\section{Disclosure statement}

No potential conflict of interest was reported by the authors.

\section{Funding}

This work was supported by Fundação para a Ciência e a Tecnologia [grant number PTDC/EGE$\mathrm{ECO} / 12499 / 2009]$.

\section{References}

Avdeitchikova, S. (2008). On the structure of the informal venture capital market in Sweden: Developing investment roles. Venture Capital an International Journal of Entrepreneurial Finance, 10(4), 55-85. doi:10.1080/13691060701605504

Avdeitchikova, S. (2009). False expectations: Reconsidering the role of informal venture capital in closing the regional equity gap. Entrepreneurship and Regional Development, 21(2), 99-130.

Bank of Portugal. (2012). Análise sectorial das sociedades não financeiras em Portugal 2010/2011. Lisboa: Estudos da Central de Balanços. 
Bank of Portugal. (2013). Relatório do Conselho de Administração - A Economia Portuguesa em 2012. Lisbon: BANCO DE PORTUGAL.

Bilau, J., \& Sarkar, S. (2016). Financing innovative start-ups in the Portuguese context: What is the role of business angel networks? Journal of the Knowledge Economy, 7, 920-934.

Boyns, N., Cox, M., Spires, R., \& Hughes, A. (2003). Research into the enterprise investment scheme and venture capital trusts. Cambridge: PACEC.

Carpentier, C., \& Suret, J.-M. (2016). The effectiveness of tax incentives for business angels. In C. Mason \& H. Landström (Eds.), Handbook of research on venture capital: Vol. 3. Business angels (pp. 327-354). Cheltenham: Edward Elgar.

Centre for Strategy \& Evaluation Services LLP. (2012). Evaluation of EU Member State business angel markets and policies, UK. Sevenoaks: Centre for Strategy \& Evaluation Services. Retrieved from www.cses.co.uk

Clark, C. (2008). The impact of entrepreneurs' oral 'pitch' presentation skills on business angels' initial screening investment decisions. Venture Capital: An International Journal of Entrepreneurial Finance, 10(3), 257-279.

Collewaert, V., Manigart, S., \& Aernoudt, A. (2010). Assessment of government funding of business angel networks in Flanders. Regional Studies, 44(1), 119-130.

COMPETE. (2013). Programa Operacional Factores de Competetitividade: Relatório Anual de Execução 2012. Lisbon: POFC (Programa Operacional Fatores de Competitividade).

Dougherty, C. (2016). Introduction to econometrics (5th ed.). Oxford: Oxford University Press.

European Business Angels Network (EBAN). (2008). EBAN Annual Report. Retrieved from http:// www.eban.org/wp-content/uploads/2013/07/EBAN-Activity-Report-of-Year-2008.pdf

European Business Angels Networks. (2016). European early stage market statistics 2015. Brussels: European Business Angels Networks.

European Central Bank. (2013). Assessing the retail bank interest rate pass-through in the euro area at times of financial fragmentation. ECB Monthly Bulletin article (August). European Central Bank.

European Commission. (2003). Benchmarking business angels (BEST Report No.1). Brussels: European Communities. Pot OECD, 2011.

European Commission. (2011). The economic adjustment programme for Portugal. DirectorateGeneral for Economic and Financial Affairs, Occasional Papers 79.

Freear, J., Sohl, J. E., \& Wetzel, W. E., Jr., (1994). Angels and non-angels: Are there differences? Journal of Business Venturing, 9, 109-123.

Gaston, R. J. (1989). Finding venture capital for your firm: A complete guide. New York, NY: Wiley. GEM Portugal. (2013). GEM Portugal 2013 - 2004-2013: Uma Década de Empreendedorismo em Portugal. Global entrepreneurship monitor GEM Portugal 2013. Retrieved from http:// empreende.service.develag.com/storage/app/media/GEM\%20Portugal\%202013.pdf

Harrison, R. T., \& Mason, C. M. (1996). Developing the informal venture capital market: A review of DTI's informal investment demonstration projects. Regional Studies, 30, 765-771.

Hayton, K., Thorn, G., Percy, V., Boyd, C., \& Latimer, K. (2008). Evaluation of the Scottish Coinvestment Fund: A report to Scottish enterprise. Glasgow: Hayton Consulting.

IFD. (2013). Instituição financeira de desenvolvimento: Fundamentação e modelos de criação. Relatório do grupo de trabalho interministerial, Lisboa, Outubro 2013.

Investing in Portugal, FT special report. (2014, December 5). Financial Times.

Jevčák, A., \& Briciu, L. (2013). Drivers of diverging financing conditions across member states. Quarterly Report on the Euro Area, 12(1), 19-25.

Knyphausen-Aufseß, D., \& Westphal, R. (2008). Do business angel networks deliver value to business angels? Venture Capital: An International Journal of Entrepreneurial Finance, 10(2), 149-169.

Lahti, T. (2011). Categorization of angel investments: An explorative analysis of risk reduction strategies in Finland. Venture Capital: An International Journal of Entrepreneurial Finance, 13 (1), 49-74.

Mason, C. (2016). Researching business angels: Definitional and data challenges. In H. Landström \& C. Mason (Eds.), Handbook on research on venture capital. Volume 3: Business angels (pp. $25-$ 52). Cheltenham: Edward Elgar. 
Mason, C., Botelho, T., \& Zygmunt, J. (2016). Why business angels reject investment opportunities: Is it personal? International Small Business Journal, online first. doi:10.1177/0266242616646622

Mason, C., \& Kwok, J. (2010). Investment readiness programmes and access to finance: A critical review of design issues. Local Economy, 25(4), 269-292.

Mason, C. M. (2009). Public policy support for the informal venture capital market in Europe: A critical review. International Small Business Journal, 27(5), 536-556.

Mason, C. M., Harrison, J., \& Harrison, R. T. (1988). Closing the equity gap? An assessment of the business expansion scheme. London: Small Business Research Trust.

Mason, C. M., \& Harrison, R. T. (1997). Business angels in the UK: A response to Stevenson and Coveney. International Small Business Journal, 15(2), 83-90.

Mason, C. M., \& Harrison, R. T. (1999). Public policy and the development of the informal venture capital market: UK experience and lessons for Europe. In K. Cowling (Ed.), Industrial policy in Europe (pp. 199-223). London: Routledge.

Mason, C. M., \& Harrison, R. T. (2000). Influences on the supply of informal venture capital in the UK: An exploratory study of investor attitudes. International Small Business Journal, 18(4), 11-28.

Mason, C. M., \& Harrison, R. T. (2002). Barriers to investment in the informal venture capital sector. Entrepreneurship and Regional Development, 14(3), 271-287.

Mason, C. M., \& Harrison, R. T. (2003). 'Auditioning for money': What do technology investors look for at the initial screening stage? Journal of Private Equity, 6(2), 29-42.

Mason, C. M., \& Harrison, R. T. (2008). Measuring business angel investment activity in the United Kingdom: A review of potential data sources. Venture Capital: An International Journal of Entrepreneurial Finance, 10(4), 309-330.

Mason, C. M., \& Harrison, R. T. (2010). Annual report on the business angel market in the United Kingdom: 2008/09. Sheffield: Department of Business, Innovation and Skills.

Mason, C. M., \& Harrison, R. T. (2015). Business angel investment activity in the financial crisis: UK evidence and policy implications. Environment and Planning C: Government and Policy, 33(1), 43-60.

OECD. (2011). Financing high-growth firms: The role of angel investors. Paris: OECD publishing.

OECD. (2012). Portugal. In Restoring Public Finances, 2012 Update. OECD publishing.

Owen (Baldock), R., \& Mason, C. (2016). The role of government co-investment funds in the supply of entrepreneurial finance: An assessment of the early operation of the UK angel co-fund. Environment and Planning C: Government and Policy. Online first. doi:10.1177/0263774X16667072

Peters, B. (2009). Early exits: Exit strategies for entrepreneurs and business angel investors (but maybe not venture capitalists). New Westminster, British Columbia, Canada: Meteor Bytes.

Portugal aims for clean bailout deal. (2014, January 28). Financial Times.

San José, A., Roure, J., \& and Aernoudt, R. (2005). Business angel academies: Unleashing the potential for business angel investment. Venture Capital: An International Journal of Entrepreneurial Finance, 7, 149-165.

Sohl, J. (2012). The changing nature of the angel market. In H. Landström \& C. Mason (Eds.), The handbook of research on venture capital: Volume II (pp. 17-41). Cheltenham: Edward Elgar.

Sohl, J. E. (2016). Angel investing. Testimony to the US Senate Small Business and Entrepreneurship Committee on 'Searching for Capital: How Venture Capitalists and Angel Investors Fund Entrepreneurs and Startup Companies'.

Stedler, H. R., and Peters, H. H. (2003). Business angels in Germany: An empirical study. Venture Capital: An International Journal of Entrepreneurial Finance, 5, 269-276.

Urdan, T. C. (2005). Statistics in plain English. Mahwah, NJ: Lawrence Erlbaum.

Wetzel, W. E. (1981). Informal risk capital in New England. In K. H. Vesper (Ed.), Frontiers of entrepreneurship research 1981 (pp. 217-245). Wellesley: Babson College.

Wetzel, W. E., Jr. (1987). The informal venture capital market: Aspects of scale and market efficiency. Journal of Business Venturing, 2, 299-313. 